HORTSCIENCE 26(1):4042. 1991.

\title{
Centipedegrass Response to Plant Growth Regulators
}

\author{
Jack D. Fry' \\ Department of Horticulture, Louisiana State University, Baton Rouge, \\ LA 70803
}

Additional index words. turfgrass, Eremochloa ophiuroides, ethephon, glyphosate, mefluidide, paclobutrazol, sethoxydim, sulfometuron methyl

\begin{abstract}
A field study was conducted in southern Louisiana to screen several plant growth regulators (PGRs) for efficacy in suppressing centipedegrass [Eremochloa ophiuroides (Munro) Hack.] vegetative growth and seedhead production. PGRs were applied in three sequential treatments in 1988 and included ethephon, glyphosate, mefluidide, paclobutrazol, sethoxydim, and sulfometuron methyl. Ethephon $\left(5.0 \mathrm{~kg} \cdot \mathrm{ha}^{-1}\right)$ suppressed mean centipedegrass vegetative growth by $15 \%$ with no turf injury. Mefluidide $\left(0.6 \mathrm{~kg} \cdot \mathrm{ha}^{-1}\right)$ and ethephon reduced mean seedhead number by $55 \%$ and $61 \%$, respectively. Glyphosate $\left(0.6 \mathrm{~kg} \cdot \mathrm{ha}^{-1}\right)$ suppressed vegetative and reproductive growth, but caused unacceptable phytotoxicity and reduced centipedegrass cover and quality during Spring 1989. Use of ethephon or mefluidide to reduce trimming requirements or mower operation in hazardous areas may be an effective means of inhibiting centipedegrass growth. Chemical names used: $N$-(phosphonomethyl) glycine (glyphosate); $N$-[2,4-dimethyl-5-[[(trifluromethyl) sulfonyl]amino] phenyl]acetimide (mefluidide); 2-[1(ethoxyimino)butyl] -5- [2-(ethylthio) propyl]-3-hydroxy-2-cycIohexen-l-one (sethoxydim); 2-[[[[(4,6-dimethyl-2 -pyrimidinyl) amino] carbonyl]amino] sulfonyl]benzoic acid (sulfometuron methyl); (2-chloroethyl) phosphoric acid (ethephon); $( \pm)-\left(R^{*} R^{*}\right) B-[(4-$ chlorophenyl)methyl]aA,l-dimethylethyl) -1 H -1,2,4-triazole-l-ethanol (paclobutrazol).
\end{abstract}

Centipedegrass is a warm-season turfgrass that is used throughout the southeastern United States and that has a low-N requirement and a relatively slow vegetative growth rate (Busey and Meyers, 1979). Centipedegrass is generally mowed weekly to maintain uniformity

Received for publication 20 Feb. 1990. The cost of publishing 'this paper was defrayed in part by the payment of page charges. Under postal regulations,thispaper therefore must be hereby marked advertisement solely to indicate this fact. ${ }^{1}$ Assistant Professor. and remove unsightly seedheads that quickly elongate above the vegetative turf canopy. In southern Louisiana, centipedegrass grows actively for 8 months each year; therefore, mowing is laborious and costly. An alternative to mowing is the use of plant growth regulators (PGRs) to reduce vegetative growth and seedhead numbers. Although PGRs have been evaluated extensively on cool-season grasses, less research has been conducted on warm-season grasses, centipedegrass in particular, to identify effective PGRs.

Much of the research conducted with PGRs 
Table 1. Effect of plant growth regulators on mean common centipedegrass canopy height, seedhead number, and turf quality in 1988, and turf recovery in Spring 1989 indicated by cover and turf quality.

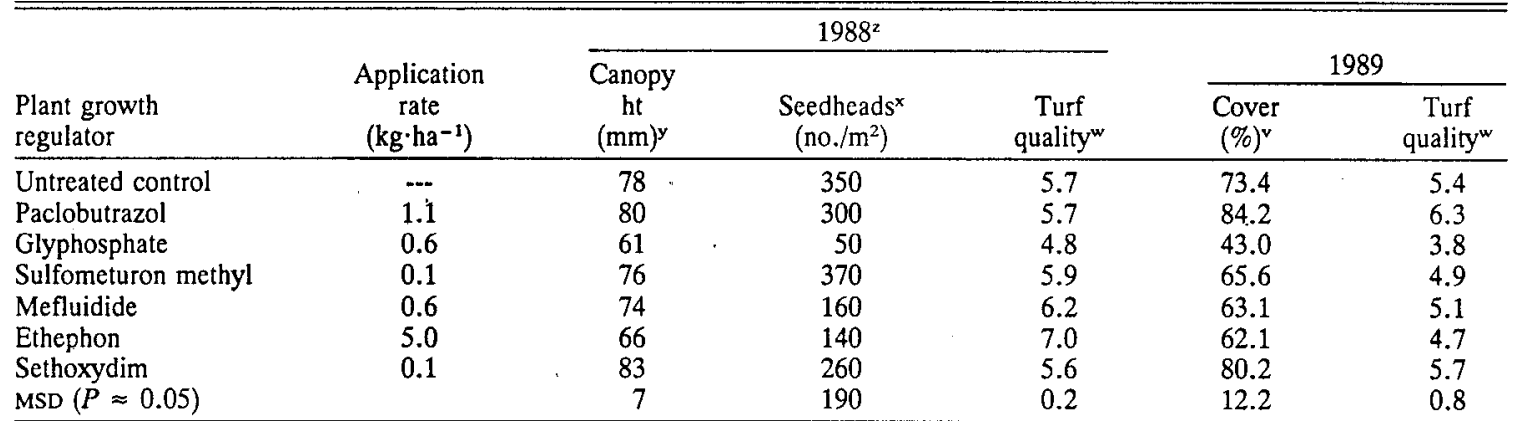

${ }^{2}$ Plant growth regulators were applied 20 May, 18 July, and 23 Aug. 1988.

${ }^{y}$ Means of four replicates measured on 14 dates between 27 May and 3 Oct. 1988.

${ }^{x}$ Means of four replicates counted on four dates between 14 July and 26 Sept. 1988.

"Turf quality was rated visually on a 0 to 9 scale, where $0=$ brown, nonuniform turf with poor density; $6=$ acceptable quality

for a home lawn: and $9=$ optimum color, density, and uniformity of height. Means of four replicates evaluated on 16 dates between

27 May and20 Oct. 1988 and on five dates between 4 Apr. and 9 June 1989.

'Means of visual turf cover data collected from four replicates on five dates between 4 Apr. and 9 June 1989.

on warm-season turfgrasses has been done with bermudagrass [Cynodon spp. ]. In Georgia, Johnson (1988) reported that flurprimidol suppressed vegetative growth of 'Tifway' bermudagrass for 4 weeks when applied in late May. Rogers et al. (1987) observed good growth retardation of common bermudagrass with combinations of metsulfuron methyl and sulfometuron methyl in Arkansas. Hield et al. (1979) reported a 56\% reduction in vegetative growth of 'Santa Ana' bermudagrass following mefluidide application in California; seedhead production was also inhibited. In Oklahoma, Wu et al. (1976) found that mefluidide and ethephon significantly reduced bermudagrass vegetative growth and seedhead development.

Johnson (1989) observed best seedhead suppression of unmowed centipedegrass with applications of imazethapyr and mefluidide; however, the former caused significant turf injury. Because more information is needed to allow for recommendations; these studies were conducted to screen several PGRs for efficacy in suppressing centipedegrass vegetative and reproductive growth.

Research was conducted at the Burden Research Plantation, Baton Rouge, La., in 1988. Common centipedegrass growing on an Olivier silt loam (fine-silty, mixed, thermic aquic, Fragiudalfi pH 5.7; $1.7 \%$ organic matter) was maintained at $\approx 60 \mathrm{~mm}$ before treatment. Nitrogen was applied at $49 \mathrm{~kg} \cdot \mathrm{ha}^{-1}$ on 27 Apr. Irrigation was used throughout the study to prevent drought stress.

PGRs evaluated were paclobutrazol, glyphosate, sulfometuron methyl, mefluidide, ethephon, and sethoxydim. Glyphosate is a nonselective herbicide, whereas sulfometuron methyl and sethoxydim are selective herbicides. Sethoxydim is labeled for use on centipedegrass. Paclobutrazol and mefluidide are labeled as PGRs. Treatments (Table 1) were initially applied on 20 May, and sequential applications were made to the same plots on 18 July and 23 Aug. Turf was mowed back to a height of $60 \mathrm{~mm}$ before each application. No additional mowing was performed. PGRs were applied at $207 \mathrm{kPa}$ pressure using a $\mathrm{CO}_{2}$-powered, single-nozzle backpack sprayer calibrated to deliver 468 liters water/ha. PGRs were not watered-in after application. A nonionic surfactant (Ortho X-77, Chevron Chemical Co., San Francisco) was added to the sethoxydim treatment at $0.4 \%(\mathrm{v} / \mathrm{v})$. Plots measured $1.5 \times 1.5 \mathrm{~m}$ and were arranged in a randomized complete-block design with four replications.

Data collected in 1988 included canopy height, seedhead number, and turf quality. Three canopy height measurements were determined in each plot using a method described by Demoeden (1984) in which a ruler is set upright on the soil surface and a 10cm-diameter cardboard disk mounted on the ruler is dropped onto the top of the vegetative turfgrass canopy. Seedhead numbers were determined by randomly tossing a $20 \times 20$ $\mathrm{cm}$ template three times per plot and counting seedheads. Turf quality was rated visually on a 0 to 9 scale, where $0=$ brown, nonuniform turf with poor density; $6=$ acceptable turf quality for a home lawn; and 9 = optimum color, density, and uniformity of height. Turf chlorosis or color enhancement following PGR application was included in turf quality scores. Effects of 1988 PGR applications on centipedegrass recovery in Spring 1989 were determined by visually rating plots for percent cover using a $\mathrm{O}$ to $100 \%$ scale, where $\mathrm{O}=$ no cover and $100 \%=$ complete cover. Multiple observations throughout each year were pooled as repeated measures. Means of data collected throughout the study for all variables were subjected to analysis of variance and separated by minimum significant difference (MSD) from the Wailer-Duncan $k$ ratio $t$ test $(k=100, P \approx 0.05)$.

Glyphosate and ethephon reduced mean centipedegrass canopy height by $22 \%$ and $15 \%$, respectively (Table 1 ), but glyphosate caused unacceptable turf yellowing. Ethephon provided 4 to 6 weeks of vegetative growth suppression following all three applications (data not presented). Mefluidide suppressed vegetative growth for 4 weeks after application in August, but not following May and July treatments (data not presented).
Centipedegrass treated with glyphosate, mefluidide, and ethephon produced $85 \%$, $55 \%$, and $61 \%$ fewer seedheads, respectively, than untreated turf (Table 1). Other PGRs were not effective seedhead suppressants.

Ethephon-treated centipedegrass exhibited better quality in 1988 than turf treated with other PGRs (Table 1). This difference is attributed to a more uniform, shorter centipedegrass turf canopy; fewer seedheads, and a desirable blue-green turf color. Mefluidide also improved mean centipedegrass turf quality by reducing seedhead populations and providing a more uniform turf canopy height. Slight turf yellowing was observed following each mefluidide application. Glyphosate, although it suppressed vegetative growth and seedhead development, caused severe plant chlorosis and reduced stand density, resulting in unacceptable turf quality throughout most of the study. Glyphosate-treated centipedegrass also had poorer quality ratings and less turf cover than untreated turf during Spring 1989. Thus, its use as a PGR on centipedegrass is precluded.

Results indicate that paclobutrazol, sulfometuron methyl, and sethoxydim do not effectively suppress centipedegrass vegetative growth or seedhead development at the levels evaluated herein. In Georgia, Johnson (1989) also observed poor centipedegrass seedhead inhibition with sethoxydim and sulfometuron methyl.

Wu et al. (1976) reported stimulation of bermudagrass growth when ethephon was applied at levels $\leq 6.7 \mathrm{~kg} \cdot \mathrm{ha}^{-1}$ in the greenhouse. In the field, however, ethephon amounts $>6.7 \mathrm{~kg} \cdot \mathrm{ha}^{-1}$ inhibited bermudagrass growth. The current results indicate that ethephon applied at $5.0 \mathrm{~kg} \cdot \mathrm{ha}^{-1}$ suppresses centipedegrass growth and may enhance turf quality. Elongation of leaf sheaths following ethephon application, as reported in Kentucky bluegrass (Pea pratensis L.) (Poovaiah and Leopold, 1973; Demoeden, 1984), was not observed in centipedegrass.

Mefluidide suppressed centipedegrass seedhead production, but did not consistently retard centipedegrass vegetative growth. 
Johnson (1989) reported $78 \%$ suppression of centipedegrass seedheads 6 weeks after mefluidide application $\left(0.6 \mathrm{~kg} \cdot \mathrm{ha}^{-1}\right)$ one year, but only $21 \%$ inhibition the following year.

Although this study has shown that some PGRs, such as ethephon and mefluidide, may effectively inhibit growth of foliage and/or seedheads, several problems reduce the feasibility of extensive PGR use on centipedegrass. First, PGRs do not generally have a broad-spectrum effect. Therefore, any weeds that are present in the turf gain a competitive edge when the growth rate of centipedegrass is reduced. Secondly, stage of seedhead development at PGR application time may affect the degree of seedhead suppression. Johnson (1989) and I observed inconsistent PGR effects on centipedegrass seedhead growth. DiPaola et al. (1986) found that PGR efficacy on cool-season grasses depends on the stage of seedhead development at the time of application.

More research is needed to determine the effects of environment on PGR performance and optimum application times to reduce centipedegrass vegetative and reproductive growth. In areas where lethal amounts of a nonselective herbicide are used to reduce trimming requirements (e.g., around trees and along fence lines) or where mower operation is hazardous, the advantages of using ethephon or mefluidide to reduce centipedegrass mowing requirements may overcome potential disadvantages.

\section{Literature Cited}

Busey, P. and B.J. Meyers. 1979. Growth rates of turfgrasses propagated vegetatively. Agron. J. 17:817-821.

Dernoeden, P.H. 1984. Four-year response. of a Kentucky bluegrass-red fescue turf to plant growth retardants. Agron. J. 76:807-813.
DiPaola, J. M., W.B. Gilbert, and W.M. Lewis. 1986. Plant growth regulator timing research. Transportation Res. Circ. 307:11-12.

Hield, H., S. Hemstreet, V.A. Gibeault, and V.B. Youngner. 1979. Warm season turf growth control with Embark. Calif. Agr. 33:15-16.

Johnson, B.J. 1988. Influence of nitrogen on the response of 'Tifway' bermudagrass to flurprimidol. Weed. Technol. 2:53-58.

Johnson, B.J. 1989. Response of centipedegrass to plant growth regulators and frequency of mowing. Weed Technol. 3:48-53.

Poovaiah, B.W. and A.C. Leopold. 1973. Effects of ethephon on growth of grasses. Crop Sci. 13:755-758.

Rogers, J. N., E.M. Miller, and J.W. King. 1987. Growth retardation of bermudagrass with metsulfuronmethylandsulfometuronmethyl.Agron. J. 79:225-229.

Wu, Chu-huang, H.R. Myers, and P.W. Santelman. 1976. Chemical retardation of bermudagrass turf. Agron. J. 68:949-952. 